\title{
Xiaomi invades the smartphone market in India
}

\author{
Rahela Tabassum $\cdot$ Shehbaz Ahmed
}

Published online: 27 May 2020

(C) Indian Institute of Management Calcutta 2020

\begin{abstract}
The case study is based on Xiaomi Corporation, a Chinese Public company, headquartered in Beijing, China. Xiaomi (the word Xiaomi means millet which means a "grain" that is a staple diet in various parts of the world) is the world's fourth largest smartphone (a smartphone is a mobile phone with various functions of a computer) company based on total shipments. It produces low-cost but high specification smartphones. Xiaomi which has emerged as the top smartphone brand in India also manufactures consumer electronics and mobile apps. Currently, Xiaomi revenue comes from the sale of products like smartphones, Iot, lifestyle products, advertising services and internet value-added services (which include online games). According to IDC India, Xiaomi has $29.7 \%$ of market share at the end of Q218. The organization has achieved an astounding growth. Xiaomi's India revenue jumped 175\% in 2017-2018 to Rs. 230.6 billion year on year. The firm that sells smartphones under the brand Redmi and Mi had a net profit of Rs. 2.93 bn in 2017-2018 (according to IDC, Counterpoint Research). Xiaomi Corporation which was founded in April 2010 was listed in the Hong Kong stock exchange on July 9, 2018. Xiaomi being
\end{abstract}

R. Tabassum $(\bowtie) \cdot S$. Ahmed

Amjad Ali Khan College of Business Administration,

Banjara Hills, Hyderabad, Telangana, India

e-mail: dr.rahelatabassum@gmail.com

S. Ahmed

e-mail: professorshehbaz@yahoo.com the "Coolest Company" in the heart of its users is committed to continuous innovation. Xiaomi has launched its first smartphone in August 2011 and became the largest smartphone company in China by 2014. Xiaomi the Bengaluru headquartered firm has entered the Indian market on July 15, 2014, in partnership with Flipkart to sell its smartphone with a concept of Flash sales. It has become a global player from a startup company in smartphone market in a span of not even a decade. Samsung of South Korea and Xiaomi of China are expected to continue their fight for top slot in 2019. The study aims to analyse the Indian smartphone market with the business model, marketing mix and innovative strategies of Xiaomi in order to identify its strengths, weaknesses, opportunities and challenges. The finding indicates that the company needs to focus on improving its product quality, advertising and distribution network to face fierce competition. Through the innovative strategies of Xiaomi, it is likely to become a game changer in the near future.

Keywords MI · Global player · Serial entrepreneur · MIUI

\section{Xiaomi's Mission Statement:}

At Xiaomi, we strive to create the highest quality products at the lowest possible prices to provide 
people with access to the necessary tools and services that connect them to the world and, ultimately, their dreams.

\section{Introduction}

The use of smartphones has seen spectacular growth in the recent past. Most users have shifted from simple phones to smartphones. IBM was the first company to introduce smartphones in the year 1990. Later, it was followed by Nokia, Ericsson, Apple, Blackberry, Samsung and others. The smartphone market has plenty of new players who manufacture and sell smartphones. Xiaomi popularly known as "Apple of China" was founded 7 years ago on April 6, 2010, by a serial Entrepreneur Lei Jun in Beijing and became the leading smartphone brand in the first largest market China and the second largest market India. Later, it expanded its business in other countries like Malaysia, Singapore, Indonesia, Philippines and South Africa. It has entered the Western market but couldn't catch enough attention. The founder of Xiaomi has an estimated net worth of US\$ 12.5 billion which makes him the 11th richest person of China and 118th richest person of the world. The market valuation of Xiaomi is more than the US \$ 46 billion.

Initially, Xiaomi was a startup technology-based company and in a span of fewer than 5 years has become a global player in the smartphone market. Xiaomi has launched its first smartphone in August 2011 and became the largest smartphone company in China by 2014. It is the world's fourth largest smartphone manufacturer after Samsung, Huawei and Apple. Its target market is the price-sensitive lower middle-income group of customers and millennials who prefer smartphones in a lower price range.

The serial entrepreneur Lei Jun has founded Xiaomi in 2010 based on the vision "Innovation for everyone". According to the Wall Street Journal, Xiaomi awarded the founder and CEO Lei Jun about $\$ 1.5$ billion in stock. In July 2019, Xiaomi was listed in Fortune Global 500 companies and became the youngest Global 500 companies of 2019. It ranks 468th among all categories and ranks 7 th in the internet services and retail category (Xiaomi TeamAug 20, 2019).
It entered the Indian market on July 15, 2014, in partnership with Flipkart to sell its smartphone Mi 3 whose price was Rs. 13,999. It was an exclusive sales tie-up with Flipkart, and the Mi phones were sold within $30 \mathrm{~min}$ on the very first day. Xiaomi India's focus is to design high-quality products and make it available at accessible prices to the world.

\section{Objectives}

1. To understand the business strategies and competitiveness of Xiaomi India in the smartphone segment.

2. To evaluate the marketing mix model which provides guidelines to Xiaomi India to put the right product in the right place at the right time and price.

3. To analyse the major challenges faced by Xiaomi India in the arena of smartphones.

4. To conduct a SWOT analysis to assess Xiaomi India's current position and how the company capitalizes its opportunities in the Indian market

\section{Xiaomi: an overview}

Xiaomi Corporation which was founded in April 2010 was listed in the Hong Kong stock exchange on July 9, 2018. Xiaomi being the "Coolest Company" in the heart of its users is committed to continuous innovation.

Xiaomi has launched its first smartphone in August 2011 and became the largest smartphone company in China by 2014. Xiaomi India the Bengaluru headquartered firm has entered the Indian market on July 15, 2014, in partnership with Flipkart to sell its smartphone with a concept of Flash sales. It has become a global player from a startup company in the smartphone market in a span of not even a decade. Samsung of South Korea and Xiaomi of China are expected to continue their fight for the top slot in 2020.

In a developing economy like India, the smartphones are unable to reach the masses due to its high prices. Mr Manu Jain, the CEO of Xiaomi India who acts like a nimble startup, maverick ${ }^{1}$ in risk taking,

$\overline{1}$ Maverick- - ne who doesn't go along with group or party. 
Fig. 1 Journey of Xiaomi India from the time of its inception. Source:

Economic Times, Mar 17, 2019
Penetration of Xiaomi in the Indian smartphone market:

Xiaomi's Pole Vault

\begin{tabular}{|c|c|}
\hline $\begin{array}{l}\text { Started } \\
\text { India } \\
\text { operations } \\
\text { in July } \\
\mathbf{2 0 1 4}\end{array}$ & $\begin{array}{c}\text { Had a } \\
\text { meagre } \mathbf{3} \% \\
\text { market } \\
\text { share in } \\
2015\end{array}$ \\
\hline
\end{tabular}

Leapfrogs from $6.4 \%$ in

third quarter of last year

to $\mathbf{2 3 . 5 \%}$ in Q3 of $\mathbf{2 0 1 7}$,

making it top of the charts

along with Samsung

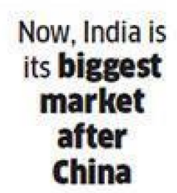

nimble in decision-making but aggressive in execution is aiming to make its foot stronger in the Indian market by targeting people who have been untouched by the telecom revolution. Xiaomi popularly known as "Apple of China" entered the Indian market with an exclusive sales tie-up with Flipkart. In a very short span, the company has acquired the number one position in the Indian smartphone market surpassing even the Korean giant Samsung (Fig. 1).

\section{Penetration of Xiaomi in the Indian smartphone market}

Xiaomi India has started its operations in India in 2014 and had a meagre share of $3 \%$ in 2015.

However, in 2016 it has clocked a revenue of $\$ 1$ billion and became profitable (Fig. 2).

Xiaomi India's revenue jumped $175 \%$ in 2017-2018 to Rs. 230.6 billion year on year. The firm that sells smartphones under the brand Redmi and Mi had a net profit of Rs. 2.93 bn in 2017-2018 (according to IDC, Counterpoint Research).

The documents available at the Registrar of Companies show that in 2016-2017, Xiaomi India had a net profit of Rs. 1.64 bn and sales of Rs. 83.8 bn. According to Canalys (research agency), Xiaomi smartphones continued to experience high growth in the Indian smartphone market and ranked first in terms of market share by shipments in the second quarter of 2018.

India is an emerging market for smartphones. According to Counterpoint Technology Market Research and Cyber Media Research, although the global annual sales of smartphones have declined, the Indian smartphone market has grown by $12 \%$ approximately from about 134 million to 150 million in 2017.

According to International Data Corporation (IDC), in 2018, Xiaomi shipped $11.7 \mathrm{mn}$ smartphones and became the top brand in the Indian market with $27.3 \%$ in the third quarter of 2018. Xiaomi India was able to grow to a new height with its successful Redmi 5A and Redmi Note 5 Pro series. It also has refreshed it Redmi 6/A/Pro portfolio.

The smartphone segment is the major growth driver in India. According to the ET report, Xiaomi's smartphone shipments in India are going to register a $22 \% \mathrm{CAGR}^{2}$ in $2018-20 \mathrm{E}$ with market share gradually rising to $34 \%$ in $2020 \mathrm{E}$ from $30 \%$ in 2018 . Among the emerging markets, India enjoyed the strongest growth of $14 \%$ YoY in 2017 to $8 \%$ of global market share, up from $7 \%$ in 2016 (Fig. 3).

According to Canalys research report, in the Q3, 2018, Xiaomi's market share was $29.8 \%$ with an annual growth of $31.5 \%$. Samsung market share was $23 \%$ with a negative annual growth of $1.6 \%$. The market shares of Vivo and Oppo were 11.1 and $8.8 \%$, respectively. The annual growth rate was $12.3 \%$ and $-2.0 \%$, respectively (Fig. 4).

According to Canalys Smartphone Analysis, Jan 2020 Xiaomi India was able to maintain its top position in 2019 with an annual growth of $5 \%$ and a market share of $29 \%$.

\section{Xiaomi's smartphone shipments across the globe}

According to Macquarie Research, July 2018, Company model has $15 \%$ CAGR for unit smartphone shipments in India in 2018-20E, driven by rising population and smartphone penetration rates. When compared to the rest of the globe, Xiaomi's popularity is incredibly high in India (Figs. 5, 6).

The performance streaks of Xiaomi have shown no signs of abating. The company has cemented its lead in the country by shipping more than 12 million

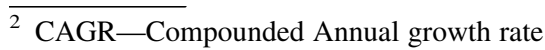




\section{- Revenue - Net Profit}

IN NUMBERS Xiaomi's revenue jump 175 per cent in FY18 (₹ billion)

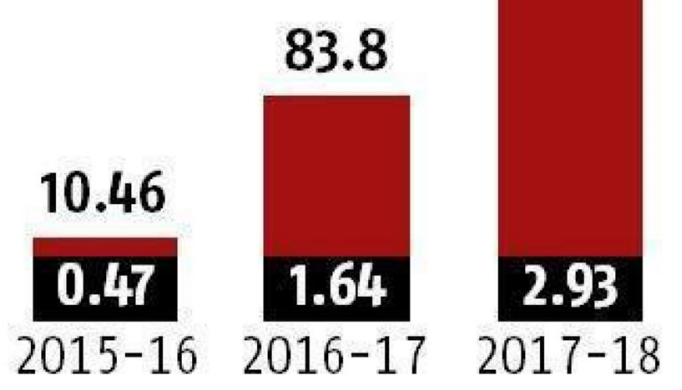

\section{Smartphone marketshare since its India entry in mid-2014(\%)}



Market share in Jul-Sep, 2018 pe riod Sources: Registrar of Companies, IDC, Counterpoint Research

Fig. 2 Xiaomi revenue and net profit (in Billion Rs) in recent years. Source: IDC Counterpoint Research

smartphones in Q3 2018. Samsung was able to ship 9.3 million smartphones in Q3 2018. Vivo and Oppo came the third and fourth with 4.5 million and 3.6 million shipments, respectively.
SWOT analysis of Xiaomi

Strengths

(a) Growing market Growing market for smartphones in developing countries is a major strength of Xiaomi, especially in the Asian market. India, China and Pakistan are the largest consumers in the Asian market. Currently, Xiaomi products are available in more than 80 countries around the world and have a leading foothold in many of them.

(b) Pricing strategy The pricing strategy adopted by Xiaomi is penetrative pricing. It prices its product very reasonably. It offers the right quality at the right price to its customers.

(c) Quality products At a very low price, the company sells good quality products on the e-commerce portal. The smartphones of Xiaomi are regularly rated very high on quality.

(d) Consistent strong revenues and profit The Company has seen a consistent increase in the annual growth for the last 4 years which enabled innovations in the smartphone segment.

(e) Advance technology The smartphones of Xiaomi are technologically advanced and are well known for its cameras which are very high in resolution. Xiaomi is often at the leading edge of new technology as it offers innovative and featured products.

(f) Increased brand awareness The increase in brand awareness of Xiaomi smartphones has resulted in higher sales across the Asian market.

(g) Online marketing The Flash sales of Xiaomi smartphones on e-commerce portal have made consumers go crazy, and the company was able to sell the smartphones at very reasonable prices in a limited time.

(h) Investment in $R \& D$ The Company invests heavily in $R \& D$. Its major $R \& D$ expense is towards cost advantage ${ }^{3}$ rather than on differential advantage. ${ }^{4}$

\footnotetext{
${ }^{3}$ Is something where the focus of the company is on reducing the cost.

${ }^{4}$ Is something where the focus is on developing different features.
} 


\section{India smartphone shipments, market share and annual growth (by vendor),} Canalys Smartphone Market Pulse Q3 2018

\begin{tabular}{cccccc}
\hline $\begin{array}{c}\text { Vendor } \\
\text { (company) }\end{array}$ & $\begin{array}{c}\text { Q3 2018 } \\
\text { shipments } \\
\text { (million) }\end{array}$ & $\begin{array}{c}\text { Q3 2018 } \\
\text { market share }\end{array}$ & $\begin{array}{c}\text { Q3 2017 } \\
\text { shipments } \\
\text { (million) }\end{array}$ & $\begin{array}{c}\text { Q3 2017 } \\
\text { market share }\end{array}$ & $\begin{array}{c}\text { Annual } \\
\text { growth }\end{array}$ \\
\hline Xiaomi & 12.1 & $29.8 \%$ & 9.2 & $22.5 \%$ & $31.5 \%$ \\
\hline Samsung & 9.3 & $23.0 \%$ & 9.4 & $23.1 \%$ & $-1.6 \%$ \\
\hline Vivo & 4.5 & $11.1 \%$ & 4.0 & $9.8 \%$ & $12.3 \%$ \\
\hline Oppo* & 3.6 & $8.8 \%$ & 3.6 & $8.9 \%$ & $-2.0 \%$ \\
\hline - RealMe & 0.8 & $1.9 \%$ & - & - & N/A \\
\hline Micromax & 2.6 & $6.3 \%$ & 1.6 & $3.9 \%$ & $61.5 \%$ \\
\hline Others & 8.5 & $21.0 \%$ & 13.0 & $31.8 \%$ & $-34.7 \%$ \\
\hline Total & $\mathbf{4 0 . 4}$ & $\mathbf{1 0 0 . 0 \%}$ & $\mathbf{4 0 . 8}$ & $\mathbf{1 0 0 . 0 \%}$ & $-\mathbf{0 . 9} \%$ \\
\hline
\end{tabular}

* Oppo's shipments include RealMe.

Source: Canalys Smartphone Analysis, October 2018

Fig. 3 Annual growth and market share of smartphone manufacturers in the Indian smartphone market in 2017-2018

\section{Indian smartphone shipments and annual growth}

\section{Canalys Smartphone Market Pulse: 2019}

\begin{tabular}{|c|c|c|c|c|c|}
\hline Vendor & $\begin{array}{r}2019 \\
\text { shipments } \\
\text { (million) }\end{array}$ & $\begin{array}{r}2019 \\
\text { Market share }\end{array}$ & $\begin{array}{r}2018 \\
\text { shipments } \\
\text { (million) }\end{array}$ & $\begin{array}{r}2018 \\
\text { Market share }\end{array}$ & $\begin{array}{l}\text { Annual } \\
\text { growth }\end{array}$ \\
\hline Xiaomi & 42.9 & $29 \%$ & 41.0 & $30 \%$ & $5 \%$ \\
\hline Samsung & 32.3 & $22 \%$ & 35.4 & $26 \%$ & $-9 \%$ \\
\hline Vivo & 24.7 & $17 \%$ & 14.4 & $10 \%$ & $72 \%$ \\
\hline Oppo & 16.1 & $11 \%$ & 11.2 & $8 \%$ & $44 \%$ \\
\hline Realme & 15.7 & $11 \%$ & 2.7 & $2 \%$ & $473 \%$ \\
\hline Others & 16.4 & $11 \%$ & 32.5 & $23 \%$ & $-50 \%$ \\
\hline Total & 148.2 & $100 \%$ & 137.3 & $100 \%$ & $8 \%$ \\
\hline
\end{tabular}

Source: Canalys Smartphone Analysis (sell-in shipments), January 2020

Fig. 4 Annual growth and market share of smartphone manufacturers in the Indian smartphone market in 2018-2019. Source: Canalys smartphone analysis, Jan 2020 
Xiaomi's smartphone shipments across the globe

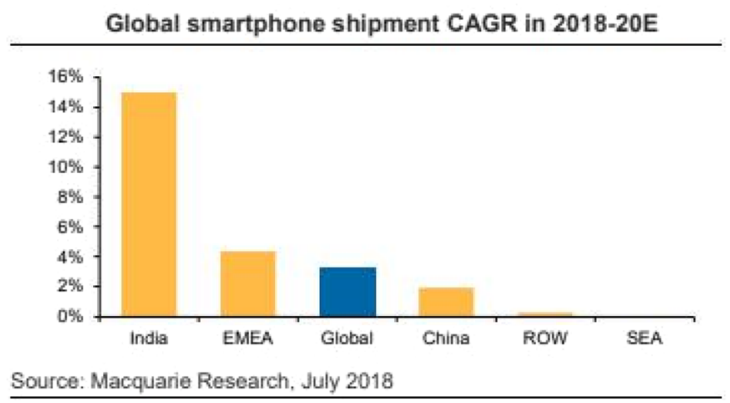

Fig. 5 Xiaomi's Global smartphone shipment. Source: Macquarie Research, July 2018

(i) Operating advantage Its low production cost is an operating advantage with excellence in engineering and innovative designs.

Weakness

(a) Brick-and-mortar store Xiaomi was able to sell its smartphone through click stores. (Flash sales). But offline sales were not so attractive. Lack of significant retail presence is a weakness.

(b) Advertising and marketing The company has spent very less on marketing and advertising. Its advertisements are not very consistent. The company spends on advertising only during a new product launch.

(c) Poor service and weak after sales Service centres of Xiaomi India are limited and provide very little after-sales support when compared to the competitors.

(d) Brand image and equity Because of being a Chinese manufacturer, the company's brand image is not as good as Samsung and Apple.

Opportunities

1. Growing urban income The per capita income is the indicator of the prosperity of an economy. According to the Ministry of statistics and programme implementation (MOSPI), the per capita income has shown a rise of $8.6 \%\left(\mathrm{FY}^{5}\right.$

\footnotetext{
${ }^{5}$ FY starts from 1st April and ends on 31st March in India
}

2017-18). However, it was slower than in the previous year growth pattern.

2. Increase in urban population According to U.N. World Urbanization prospects 2018 report, 34\% of India's population lives in urban areas. It shows an increase of $3 \%$ urban population since the 2011 census.

3. FDI norms The relaxation in FDI norms has a positive impact on the smartphone industry.

4. Growing Educated youth preferring smartphones The shopping trend of this growing educated youth has shown a preference for smartphones which are available at reasonable prices. According to the IMF, India's population mostly comprises of young people, with $41 \%$ of people in the age group of 25-40.

5. Emerging market India as an emerging market for the smartphone segment provides an opportunity to increase revenue.

Threats

1. Government regulation As the government is serious about the security of phones and user data, the company has to respond to India's data security and privacy concerns. It can be a destabilizing factor.

2. Health concern As the customers are showing a lot of concern towards health, an awareness about the dangerous effects of using mobile phones can have an impact on consumer behaviour which can in turn have a negative impact on the smartphone industry.

3. Uncertainties in share market Due to sudden fluctuation in stock prices, Xiaomi sinks after billions of shares are unlocked for sale. This will have an impact on the market share of Xiaomi India.

4. The imposition of Tax The implementation of GST has increased the prices of goods. But Xiaomi products are still priced cheaper than its competitors. However, when the government has cut the GST rates, the company has reduced its prices of smartphones to pass the benefits to its customers.

5. Increase in competition The market for smartphone makers in India is saturated as many other Chinese manufacturers (like Oppo and Vivo) are 


\section{Xiaomi ships record 12 million smartphones in Q3}

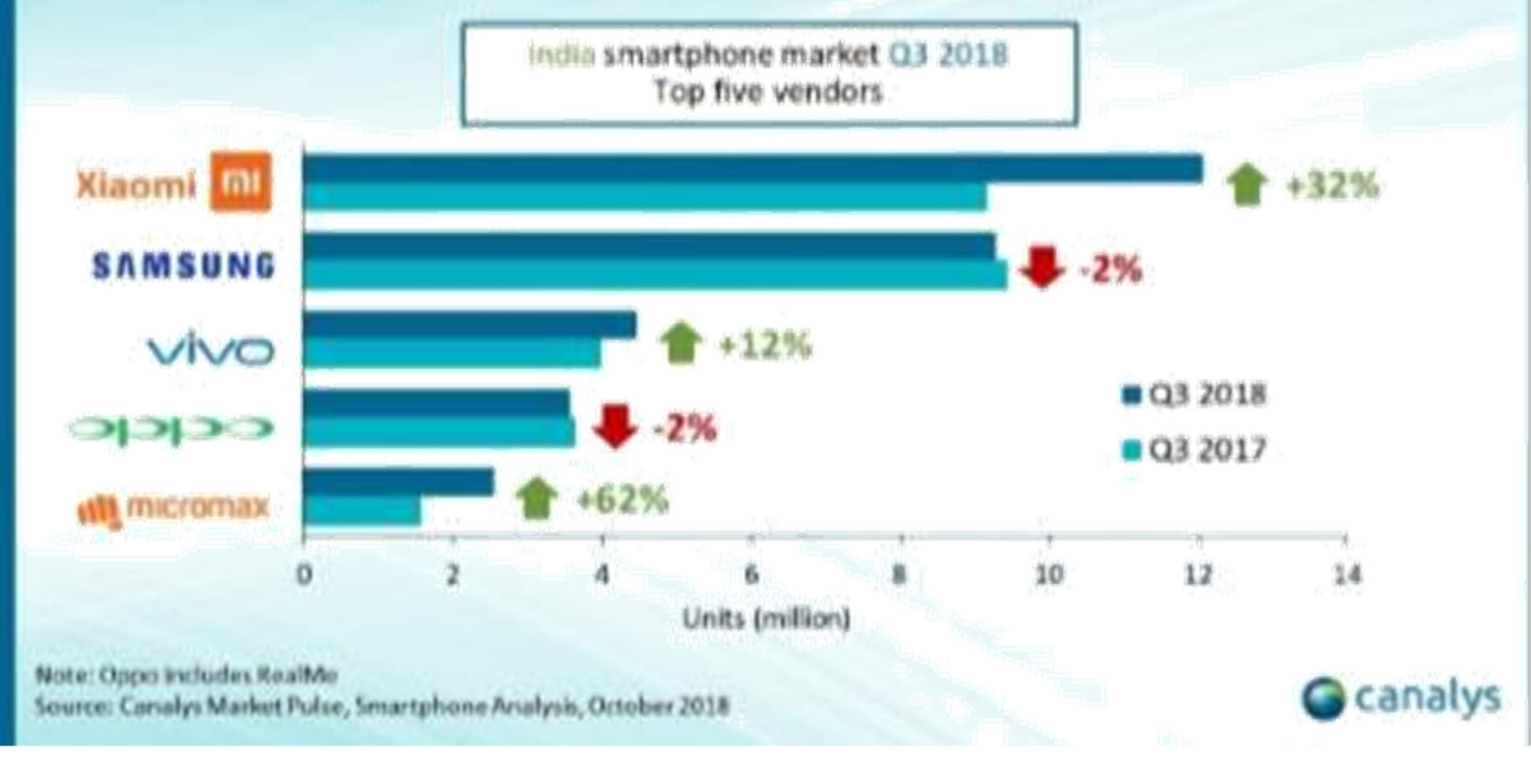

Fig. 6 India's smartphone market Q3 2018-top 5 vendors. Source: Canalys Research

coming up with affordable products with handsome specs.

\section{Business model and innovative strategies of Xiaomi India}

The Flash sale model has worked wonderfully for Xiaomi. In Flash sales, the product is generally made available only in limited quantities. The model has made the customers go crazy. The CEO of Xiaomi India Mr Manu Jain has defined himself as a Maverick. $\mathrm{He}$ is the one who challenged the status quo by doing exactly the opposite of what other mobile brands were doing in India. People have labelled him Crazy as the rivals were entrenched in brick-and-mortar stores across the country; he has adopted the online route to sell its products in a country like India. The company has got huge orders within that limited time, and Xiaomi India was able to reach its target sales in that short span (Fig. 7).

The pricing strategy of Xiaomi India is that its products are 30-50\% cheaper than the top brands like Samsung and L.G. The company's strategy is to keep just 5\% margin for itself. It assembles its products locally to take advantage of Make in India duty benefits. The Company has plans to follow the same pricing strategy for its smart appliances. Moreover, the Flash sales model concept shall also be extended to white goods.

The company focuses on a triathlon model. This creates synergies by cross-selling services and products to users, through its innovative retail concept which involves direct online sales to maximize efficiency and create a long-term direct digital relationship with the users. With its astounding growth, the company has challenged the leading smartphone makers Samsung and Apple in the Indian market (as per the Xiaomi Team report published on Aug 20, 2019).

Xiaomi India's adopts a line modernization strategy as it intends to expand its smartphone line by refreshing the portfolio and expanding the range. It also wants to expand its product category and has plans to enter the white goods market in India. All the electronic appliances which are going to be launched in India are going to be based on IoT. All these appliances are going to be launched online first and then will be available in exclusive brand stores. The most innovative strategy of the company is its keen focus to create new revenue drivers. 


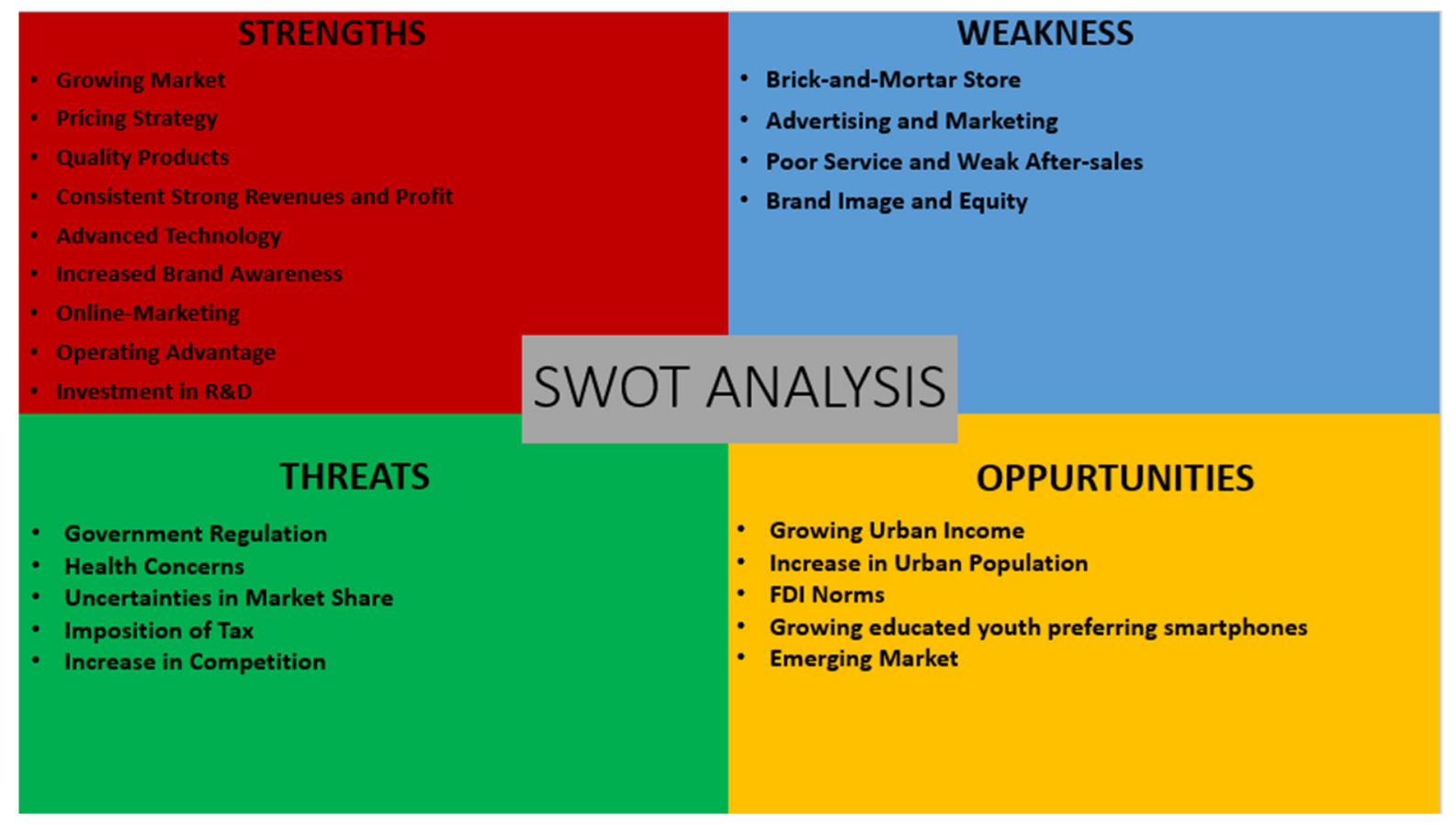

Fig. 7 SWOT analysis of Xiaomi India

\section{Financial highlights of Xiaomi India}

- Total revenue was approximately RMB51.951 billion, up $14.8 \%$ YoY;

- Gross profit was approximately RMB7.26billion, up $28.4 \%$ YoY;

- Net profit was approximately RMB1.96 billion;

- Non-IFRS adjusted net profit was approximately RMB3.64 billion, up 71.7\% YoY;

- Earnings per share were RMB0.082.

\section{Marketing strategies}

The product portfolio of Xiaomi India

The product portfolio of Xiaomi India can be categorized into Smartphones, Smart TV's and Ecosystem Accessories. The detailed items are listed below:

\section{Smartphones}
1. Mi MIX 2
2. POCO F1
3. $\mathrm{Mi} \mathrm{A} 2$
4. Redmi Note 6 Pro
5. Redmi Note 5 Pro
6. Redmi 6 Pro
7. Redmi 6
8. Redmi 6A
9. Redmi Y2
10. Redmi 5A

Other products sold by Xiaomi India

Power banks

Earphones

Air dots

Backpacks

Selfie sticks

Apparel

Chargers and cables

Bands and fitness trackers

Lifestyle

Routers

Cases and protectors

Air purifiers

VR headsets

Smart TV's 


\section{Price}

Xiaomi offers high cost-to-performance products. The company adopts a penetration pricing strategy. It offers competitively priced smartphones to its consumers. Indian customers are price sensitive and cannot afford expensive smartphones. According to Xiaomi, its success comes from consistently focusing on price and features. Xiaomi had a tough time in India because of its competitors Samsung, Oppo and Vivo. But because of its penetrative pricing strategy, Xiaomi was able to win its battle in India. However, the company for its Premium models displays aggressive specifications that might create avenues to lift Xiaomi's brand image and support premium pricing.

\section{Promotion}

Chinese smartphone giant Xiaomi India has kicked off its No.1 Mi Flash sale on Mi.com and Amazon India. Xiaomi Smartphones were up for sale online for a limited period until Friday in the month of December 2014. Xiaomi India has also partnered with Paytm, Google pay and MobiKwik to offer cashback and rewards to its customers during the Flash sales on Mi.com. The Amazon partner has offered an instant discount to its HDFC Bank Users.

Xiaomi India has taken the online route to enter into Indian market while its rivals were deeply entrenched in brick-and-mortar stores across the country. According to Manu Jain, the India head of Xiaomi as told to ET (Mar 2018), the competitors of Xiaomi were splurging millions of dollars on advertising and hiring bollywood biggies like Khans; the company was betting on word of mouth. The company believed in their blockbuster fans, i.e. their customers.

The Flash sale offered the 4 GB RAM variant of Redmi Note \% pro at a discounted price of Rs. 12,999, while Redmi Note \% Pro 6 GB RAM model was available at Rs. 11,999. The company offered huge discounts and rewards to its customers during the Flash Sales.

\section{Place}

Chinese smartphone manufacturer Xiaomi has toppled the leading smartphone maker Samsung in India
(Canalys report 2018). Xiaomi which was once considered as a cheap copycat is now able to rub shoulders with the South Korean market leader. It has set up $500 \mathrm{Mi}$ stores in rural areas and has plans to ramp up to 5000 stores in 2019 to increase its offline sales (ET 2018). The company also wants to penetrate the rural market through its offline sales. It also wants to enter into a franchise agreement with its local vendor to reach out to the masses. The size of Mi stores is on average not more than $300 \mathrm{Sq} \mathrm{ft}$. These Mi stores are likely to generate employment opportunities to over 15,000 employees in these regions.

The key factor that supports smartphones sales in India is the rising rate of internet penetration which drives online purchase. However, the internet users in Indian cities rose $10 \%$ in 2017 , but the overall internet users stayed low at around $480 \mathrm{~m}$ in 2017. It is only $35 \%$ of the total population which shows a rich upside to grow. The online channel sales of smartphones in India rose from $34 \%$ in the fourth quarter of 2017 to $36 \%$ in the first quarter of 2018 . The rising $4 \mathrm{G}$ coverage due to operator investments in $4 \mathrm{G}$ networks and $4 \mathrm{G}$ service price cuts (e.g. Reliance Jio) have accelerated smartphone market growth (Fig. 8).

Xiaomi's high cost-to-performance smartphone models have contributed to its largest market share in India. Another major factor for its rising market share is the comprehensive distribution channels which include both online and offline. Online channels contribute to $70 \%$ of Xiaomi's smartphone sales. According to IDC, riding on the growing online channel market trend (up from $34 \%$ in 4 Q17 to $36 \%$ in

Smartphone sales in India: online vs. offline

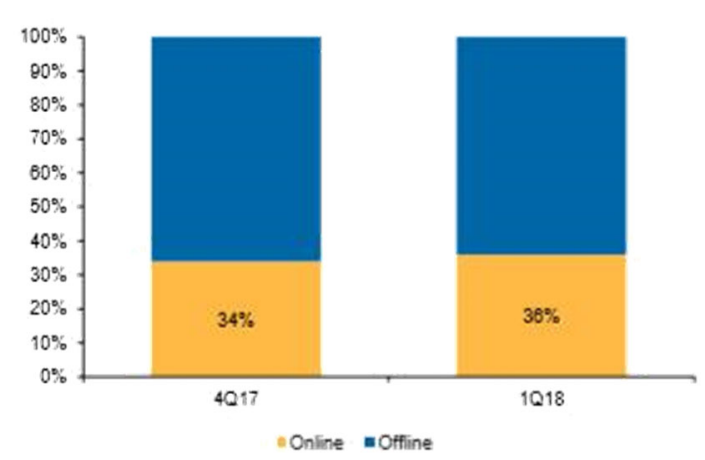

Source: IDC, Macquarie Research, July 2018

Fig. 8 Smartphone sales in India: online versus offline. Source: Macquarie Research, July 2018 
1Q18), Xiaomi also gained market share in e-Tailer shipments, to 53\% in 1Q18 from 32\% in 1Q17. In May 2017, Xiaomi started its first offline channel in India by establishing "Mi Home". By 2018, Xiaomi has 17 Mi Home stores. The company increased it to 100 stores by mid-2019.

\section{Challenges}

Although the entry of Xiaomi into the Indian market can be inspiring for many, the company was in the spotlight when the Xiaomi Redmi Note 7s exploded and the company refused to take the blame as it clarified that the damage to the phone was "customer induced" (Report of Times of India). Similar cases have been reported in the products under the Redmi brand as many phones exploded while charging. The Chinese tech company is facing criticism for its faulty batteries and manufacturing defects which caused the explosion threatening the lives of the users. However, the company's CEO Mr. Manu Jain has made a statement that the damage is caused due to external forces (Business Today Nov 2019).

Moreover, Sweden's Ericsson smartphone maker got an interim injunction against the sale of Xiaomi's smartphones claiming that Xiaomi infringed 4 of its patents which deal with GSM, GPRS, EDGE and WCDMA technologies. This caused a ban on all Xiaomi smartphones selling in India, but later on smartphones based on Qualcomm chipsets were only allowed. Ericsson later claimed that Xiaomi was selling its non-Qualcomm products through a website called www.xiaomishop.com violating its interim order. Xiaomi India defended the claim by stating that they had no stake on the website and their name was being misused (The Indian Express Nov 2017).

In another case, Coolpad a Chinese smartphone maker has filed to Indian court against its rival Xiaomi over patent infringement as India has a good reputation in protecting Intellectual Property Rights (Economic Times Jun 2018).

Though the Xiaomi smartphones are famous for their design, affordable price, high-resolution cameras and good performance, it has faced a backlash on its ad ridden MIUI. Many customers hold back from buying a Xiaomi handset because of the ads being a part of its user interface.

\section{Moving ahead}

Xiaomi India has plans to invite more of its suppliers of the component to investing in India. The Chief Marketing Officer of Xiaomi India Mr. Anuj Sharma in an interview with ET said that $95 \%$ of smartphones are made in India. One of the suppliers "Holitech Technology" has signed an MoU with the Government of A.P to start its manufacturing facility. Economic Times 2018 report says that Xiaomi India has six factories in India. The company has plans to increase its manufacturing capacity of existing plants and also opening up new plants in India to cater to the local demand of customers. Presently, Foxconn Corporation India Unit makes the company's phone locally. Foxconn and HiPad are producing $\mathrm{Mi}$ and Redmi devices in India. The company has plans to invest heavily in other manufacturers to build an ecosystem of IoT to extend its reach beyond smartphones.

To meet its growing demand for handsets, the company has partnered it with an original equipment maker FLEX to manufacture smartphones in Tamilnadu. This new plant at Tamilnadu is the seventh plant of Xiaomi India. Xiaomi India's partner Holitech Technology which supplies components to top companies except for Apple sets up a plant in Greater Noida, to invest $\$ 200 \mathrm{mn}$. The new plan has started its operations in the third quarter of 2019. It is also estimated to generate 6000 jobs in the coming 3 years. It has plans to make compact camera modules, screen modules, fingerprint modules, thin-film transistors, capacitive touch and flexible printed circuits.

To boost its growth in the smartphone segment, Xiaomi India has plans to enter India's rural market as it believes that the urban market has greater potential for the online market, but in rural India, the offline segment provides significant growth. It has launched Mi stores in the Tier 3 market of rural India to cater to the needs of India's rural smartphone user. The Chief Operating Officer of Xiaomi India Mr Murali Krishna has said in an interview with ET that they have launched 500 stores in the rural market across India.

Out of $48 \%$ of market share, $20 \%$ of the sales of Xiaomi India are offline and the rest are online. The companies plan to open their own operated and branded stores is still pending with the Government. It has plans to open around 200 retail stores in the next 2 years to increase its target market. 
Xiaomi India has plans to enter the white goods market in India which will make the country's largest smartphone maker the full-fledged consumer electronics company in India. The Company has plans to make its electronic goods as smart appliances based on IoT. These smart appliances can connect to the internet and other devices and can be operated remotely. Xiaomi India's potential electronic appliance category includes air conditioners, washing machines, refrigerators, laptops, vacuum cleaners and water purifiers.

The CEO of Xiaomi India as reported to Business Today has plans to launch various product categories in India, and their only concern is to customize the products to suit Indian customers. Xiaomi India would like to foray in areas where stringent rules and regulations don't apply. Rather than bringing products like Drones which are subjected to strict rules and regulations, the company would like to focus on flexible sectors like electric cycles and vehicles.

The company at present caters to 50 markets in the country and has plans to enter 500 markets. To expand its business, it shall make offline presence through exclusive brand stores with a range of smartphones, smart televisions and other electronic appliances. The Chinese handset maker Xiaomi is all set to install its vending machines to sell its smartphone and accessories in major Indian cities (ET May 2019). These vending machines are called "Mi Express Kiosk "and will allow its consumers to purchase smartphones and accessories. The customers can pay through credit or debit cards, cash and UPI (ET 2019).

Xiaomi India has plans to launch in the high-end range of smartphone market competing for the toe to toe with the likes of Samsung, Oneplus and Apple which currently rule the segment in 2020.

\section{Conclusion and inferences}

The handset market has witnessed stiff competition, as the bigger players are getting even bigger and marginalizing the smaller players. Samsung of South Korea and Xiaomi of China are expected to continue their fight for the top slot in 2020. The other rivals for the top five positions will be from Oppo, Vivo, Realme, HMD Global(Nokia) and Huawei/Honor. Through the innovative strategies of Xiaomi, it is likely to become a game changer in the near future.
The category expansion strategy of Xiaomi has made it a global player from just a startup firm.

Xiaomi has 190 million MAUs ${ }^{6}$ on the MIUI.MIUI (Mi User Interface) is the proprietary operating system built on the android operating system which allows users to download mobile apps from the android ecosystem. The company has 38 apps with more than 10 million MAUs and 18 apps with more than 50 million MAUs. This app includes Mi App Store, Mi Browser, Mi Music, Mi Video Apps. (ET March 2018). With such innovative strategies, Xiaomi India is building a growing tribe of fans (Xiaomi tribe). They mostly target millennials who are tech savvy and innovators of products.

The most important move of Xiaomi India about offline expansion, especially in the rural market, is the significant factor for its growth and success. Moreover, the promise to get innovative designs like foldable smartphones and bezel-less smartphones at an affordable price shall make Xiaomi India sustain the top position in the long run.

Xiaomi plans to expand its product category (entering the white goods space in Indian market) shall open newer avenues of growth in the Indian market. The appliances based on IoT will contribute to the growing revenue. Xiaomi's investment in various channels, innovative business models, growing ecosystem across devices and internet services is likely to drive market share gains in the future.

According to IDC 2018, Xiaomi has already acquired $30.6 \%$ market share in the first quarter 2019; the company's future rests on how it capitalizes the strengths and minimizes its weaknesses to create sustainable competitive advantages. Currently, the company should concentrate on improving its manufacturing facility, advertising, product quality and distribution network. The company should come up with more such innovative business practices to deal with increasing uncertainties. The case study is based on secondary data from corporate websites relevant reports, news and articles from business magazines and newspapers. The study is useful to learn about the smartphone segment in India, its growth potential and challenges, future trends. To the best of the author's knowledge, no such study was made in the past which attempts to investigate the marketing mix strategies,

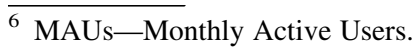


business models and challenges faced by smartphone maker Xiaomi India with the detailed analysis. The study infers that case study of Xiaomi is a lesson for all marketer's as uncertainties and challenges can appear any time, and a combination of market research and innovative strategies is necessary to face such situations.

\section{References}

"Behind the fall and rise of China's Xiaomi", 22 December 2017. Wired.com. https://www.wired.com/story/behindthe-fall-and-rise-of-china-xiaomi/

Buisness Today Nov 21, 2019, Xiaomi Redmi Note 7S allegedly explodes. https://www.google.com/amp/s/m. businesstoday.in/lite/story/xiaomi-redmi-note-7sallegedly-explodes-company-says-fire-customer-induced/ 1/390793.html

Business standard, Oct 24 2018, Xiaomi India revenue rises $175 \%$ in FY18, Mi posts net profit of Rs. 2.93 bn. https:// www.business-standard.com/article/technology/xiaomiindia-revenue-rises-175-in-fy 18-mi-posts-net-profit-of-293-bn-118102301482_1.html

Business today, December 21, 2018, Xiaomi's Redmi Go handset could soon be launched in India. https://www. businesstoday.in/technology/news/xiaomis-redmi-gohandset-could-soon-be-launched-in-india/story/302990. html

Business Today, December 20, 2018, Xiaomi No. 1 Mi Fan Sale: Here are all the deals and discounts you need to know about. https://www.businesstoday.in/technology/news/ xiaomi-no1-mi-fan-sale-here-are-all-the-deals-anddiscounts-you-need-to-know-about/story/302592.html

Business Today, Mar 20, 2019, Xiaomi makes its largest investment in India so far. https://www.businessinsider.in/ xiaomi-investment-india-new-products-launch-expected/ articleshow/68460618.cms?utm_source= contentofinterest\&utm_medium=text\&utm_campaign= cppst

Business Today Nov 15, 2018, Xiaomi is the leader of the pack in India with a market share of $27.3 \%$ in Q3. https://www. businesstoday.in/technology/news/xiaomi-is-the-leaderof-the-pack-in-india-with-market-share-of-27.3-in-q3/ story/291275.html

Business Today, November 20, 2018, Xiaomi plans to set up 5000 stores in rural India by the end of 2019. https://www. businesstoday.in/current/economy-politics/xiaomi-plansto-set-up-5000-stores-in-rural-india-by-end-of-2019/story/ 292820.html

China's Xiaomi raises 1.1 billion from investor at 45 billion valuation, Dec 9 2014. https://www.reuters.com/article/usxiaomi-fundraising/chinas-xiaomi-raises-1-1-billionfrom-investors-at-45-billion-valuationidUSKBN0K70FQ20141229

CNBC, Jan 25 2019, Here's why Apple lags behind Samsung and Xiaomi in India. https://finance.yahoo.com/news/ xiaomi-corporation-hkg-1810-financial-011724304.html. 13 Jan 2019

CNBC Markets, 22 June 2018, Xiaomi reportedly awards founder $\$ 1.5$ billion in stock ahead of IPO. https://www. cnbc.com/2018/06/22/xiaomi-reportedly-awards-founder1-point-5-billion-in-stock-ahead-of-ipo.html

First post, Jan 02, 2020, Like Xiaomi, Realme phones are now spammed with ads, but they can be disabled. https://www. firstpost.com/tech/news-analysis/like-xiaomi-realmephones-are-now-spammed-with-ads-but-they-can-bedisabled-7849991.html

Gadgets Now Oct 3, 2018, Xiaomi Mi A1 smartphone 'explodes' while charging. https://www.google.com/url?sa= t\&source=web\&rct=j\&url=https://www.gadgetsnow.com/ mobiles/xiaomi-mi-a1-smartphone-explodes-whilecharging/amp_articleshow/66049991.cms\&ved= 2ahUKEwju-

JXgrMznAhXYxDgGHUUsDdoQFjACegQIDxAL\&usg= AOvVaw2mEcinXILls3L7VOkLdPjD\&ampcf=1

Gsm arena 30 Jan 2020, Xiaomi leads in Indian smartphone sales, while Realme grows exponentially. https://www. gsmarena.com/xiaomi_leads_in_india_smartphone_sales_ while_realme_grows_exponentially_-news-41277.php

"Inside Xiaomi: The perks and perils of startups that join its ecosystem", March 2018. Tech in Asia. https://www. techinasia.com/xiaomi-ecosystem

INC 42, India Contributed $32 \%$ of Xiaomi's Total Global Revenue of $\$ 18 \mathrm{Bn}$ in 2017. https://inc42.com/buzz/indiacontributed-32-of-xiaomis-total-global-revenue/

KGI research Jun 25, 2018. https://www.kgieworld.sg/ securities/resources/ck/files/sgreport/Xiaomi_IPO\% 20Note_KGI\%20Securities\%20180625.pdf

"Lei Jun says Xiaomi is a retail business and the goal is to be another MUJI", 12 Sept 2017, Medium.com. https:// medium.com/@pandaily/lei-jun-says-xiaomi-is-a-retailbusiness-and-the-goal-is-to-be-another-muji$86636 \mathrm{~b} 388923$

Macquarie Research, Jul 8, 2018. http://www.macquarie.com/ research/disclosures

Samsung to launch India-first smartphones to counter Chinese rivals. https://www.investing.com/news/stock-marketnews/samsung-to-launch-indiafirst-smartphones-tocounter-chinese-rivals-1745537

The Business Standard, Oct 23, 2018, Smartphone shipment hits all-time high of $44 \mathrm{mn}$ units in Q2. Xiaomi leads. https:// www.business-standard.com/article/companies/ smartphone-shipment-hits-all-time-high-of-44-mn-unitsin-q2-xiaomi-leads-118102300540_1.html

The Business Today, Apr 02, 2019, Xiaomi India bets on internet services to increase revenue. https://www. businesstoday.in/buzztop/buzztop-technology/xiaomiindia-bets-on-internet-services-to-increase-revenue/story/ 333225.html

The Business Today Apr 25 2019, Xiaomi bets big on offline as online sales saturate. https://www.businesstoday.in/ technology/news/xiaomi-bets-big-on-offline-as-onlinesales-saturate/story/340430.html

The Business Today, Aug 27, 2018, Xiaomi eyes rural market in India, to open $500 \mathrm{Mi}$ stores. https://www.businesstoday. in/current/economy-politics/xiaomi-eyes-rural-market-inindia-to-open-500-mi-stores/story/281674.html 
The Business Today, Jun 19, 2019, Xiaomi Redmi Note 7 Pro is on sale today on Flipkart, Mi.com; check price, specifications. https://www.businesstoday.in/technology/news/ xiaomi-redmi-note-7-pro-sale-today-on-flipkart-micomprice-specifications/story/357244.html

The Business Today, Mar 18, 2019, Xiaomi bets big on India, invests Rs 3,500 crore in two tranches. https://www. businesstoday.in/technology/news/xiaomi-bets-big-onindia-invests-rs-3500-crore-in-two-tranches/story/328741. html

The Business Today, Mar 20,2019Xiaomi enters the digital payments market, expands handset manufacturing. https:// www.business-standard.com/article/companies/xiaomienters-digital-payments-market-expands-handsetmanufacturing-119032000049_1.html

The Business Today, Nov 15, 2018, Xiaomi is the leader of the pack in India with a market share. https://www. businesstoday.in/technology/news/xiaomi-is-the-leaderof-the-pack-in-india-with-market-share-of-27.3-in-q3/ story/291275.html

The Economic Times Apr 1, 2019, Xiaomi looks to monetise internet services in India. http://economictimes.indiatimes. com/articleshow/68666216.cms?utm_source= contentofinterest\&utm_medium=text\&utm_campaign= cppst

The Economic Times, Apr 26, 2019, Xiaomi slips but retains top spot in the Indian market. http://economictimes.indiatimes. com/articleshow/69054617.cms?utm_source= contentofinterest\&utm_medium=text\&utm_campaign= cppst

The Economic Times, Aug 23 2018, Xiaomi Q2 revenue soared $152 \%$ on strong growth in India. http://economictimes. indiatimes.com/articleshow/65504336.cms?utm_source= contentofinterest\&utm_medium=text\&utm_campaign= cppst

The Economic Times Dec 20, 2018, Xiaomi to invite more component suppliers to invest in India. http:// economictimes.indiatimes.com/articleshow/67147023. cms?utm_source $=$ contentofinterest\&utm_medium $=$ text\&utm_campaign=cppst. Accessed 3 Jan 2019

The Economic Times Dec 4, 2018, Xiaomi eyes India's rural market to fuel growth. http://economictimes.indiatimes. com/articleshow/66941007.cms?utm_source= contentofinterest\&utm_medium=text\&utm_campaign= cppst

The Economic Times Dec 6, 2018, Xiaomi leads India wearables market in Q3 2018. http://economictimes.indiatimes. com/articleshow/66969493.cms?utm_source= contentofinterest\&utm_medium=text\&utm_campaign= cppst

The Economic Times Dec 21, 2018, Xiaomi to enter white goods space in India. http://economictimes.indiatimes. com/articleshow/67184592.cms?utm_source= contentofinterest\&utm_medium=text\&utm_campaign= cppst

The Economic Times Jan 3, 2018, Smartphone sales will grow only in India. http://economictimes.indiatimes.com/ articleshow/67200234.cms?utm_source = contentofinterest\&utm_medium=text\&utm_campaign= cppst
The Economic Times Jan 9, 2019, Xiaomi sinks after billions of shares are unlocked for sale. http://economictimes. indiatimes.com/articleshow/67450375.cms?utm_source= contentofinterest\&utm_medium=text\&utm_campaign= cppst

The Economic Times Jan 2, 2019, Xiaomi TVs cheaper by up to Rs 2000. http://economictimes.indiatimes.com/ articleshow/67343214.cms?utm_source= contentofinterest\&utm_medium=text\&utm_campaign= cppst

The Economic Times Jan 4, 2019, Xiaomi, Redmi split to become different brands: report. http://economictimes. indiatimes.com/articleshow/67378086.cms?utm_source= contentofinterest\&utm_medium=text\&utm_campaign= cppst

The Economic Times Jun 01, 2018, Coolpad open to taking Xiaomi to court in India. https://www.google.com/url?sa= $\mathrm{t} \&$ source=web\&rct=j\&url=https://m.economictimes.com/ tech/hardware/coolpad-open-to-taking-xiaomi-to-courtin-india/amp_articleshow/64408739.cms\&ved= 2ahUKEwjZkLqFq8znAhVyTgGHZYDAlkQFjAAegQIBhAB\&usg= AOvVaw17Pd8MSFWpYBjfEdQgCB00\&ampcf $=1$

The Economic Times Jun 8, 2019, Samsung, Vivo \& Oppo intensify offline battle to take on Xiaomi. https:// economictimes.indiatimes.com/tech/hardware/top-brandslike-samsung-oppo-take-the-phone-battle-offline/ articleshow/69698361.cms

The Economic Times, Mar 17, 2018, Unboxing Xiaomi: how this Chinese company does what it does in India. http:// economictimes.indiatimes.com/articleshow/63342269. cms?utm_source=contentofinterest\&utm_medium = text\&utm_campaign=cppst

The Economic Times May 13, 2019, Xiaomi to sell phones via vending machines in India. http://economictimes. indiatimes.com/articleshow/69311072.cms?utm_source= contentofinterest\&utm_medium=text\&utm_campaign= cppst

The Economic Times, Nov 26, 2017, China's handset maker Xiaomi came first in India. https://economictimes. indiatimes.com/tech/hardware/how-chinas-handsetmaker-xiaomi-came-first-in-india/articleshow/61798368. $\mathrm{cms}$ ?from $=\mathrm{mdr}$

The Economic Times Nov 29, 2019, Xiaomi touches $\$ 5$ billion milestone in 2018-2019. https://economictimes. indiatimes.com/tech/hardware/xiaomi-touches-5-billionrevenue-milestone-in-india-in-2018-19/articleshow/ 72299318.cms?utm_source=contentofinterest\&utm_ medium=text\&utm_campaign=cppst

The Economic Times Sep 6, 2017, Chinese smartphone maker Xiaomi open to moving servers to India. http:// economictimes.indiatimes.com/articleshow/60382698. cms?utm_source=contentofinterest\&utm_medium = text\&utm_campaign $=$ cppst

The Hindu, Apr 09, 2019, Xiaomi set up new manufacturing units in India for smartphones, PCBs. https://www. thehindubusinessline.com/info-tech/mobiles-tablets/ xiaomi-sets-up-new-manufacturing-units-in-india-forsmartphones-pcbs/article23479556.ece

The Hindu Apr 24, 2019, Xiaomi eyes 10,000 retail stores in India. https://www.thehindubusinessline.com/info-tech/ 
xiaomi-eyes-10000-retail-stores-in-india/article26931067. ece

The Hindu, May 18, 2018, Urbanization on the rise in India. https://www.thehindu.com/news/national/growth-inurbanisation/article23925543.ece

The India Today, May 13, 2019, Mi Express Kiosk launched in India, allows buyers to purchase Xiaomi products instantly. https://www.indiatoday.in/technology/news/story/miexpress-kiosk-launched-in-india-allows-buyers-topurchase-xiaomi-products-instantly-1523687-2019-05-13

The Indian Express Nov 24, 2017, Xiaomi violating order selling non-Qualcomm smartphones. https://indianexpress. com/article/technology/mobile-tabs/xiaomi-ericssonxiaomi-mi4/

The Times of India, May 31, 2018, India's per capita income grows by $8.6 \%$ to Rs 1.13 lakh in FY. http://timesofindia. indiatimes.com/articleshow/64403580.cms?utm_source= contentofinterest\&utm_medium=text\&utm_campaign= cppst

The Week Magazine, Dec 10, 2018, Ringing in change: the rise and rise of Xiaomi Xiaomi's popularity has spread far and beyond China, especially in India. https://www.theweek. $\mathrm{in} /$ news/sci-tech/2018/11/12/ringing-in-change-the-riseand-rise-of-xiaomi.html

"The dramatic rise and fall of Xiaomi", 11 June 2016. Forbes. https://www.forbes.com/sites/ckgsb/2016/07/11/thedramatic-rise-and-fall-of-xiaomi/\#e5f93ad33da4
www.Canalys.com, Palo Alto, Shanghai, Singapore and Reading (UK)-Tuesday, 30 October 2018 India struggles to grow in Q3 despite Xiaomi's record sell-in of 12 million smartphones https://www.canalys.com/static/press_ release/2018/India-struggles-to-grow-in-Q3-despiteXiaomis-record-sell-in-of-12-million-smartphones.pdf

Xiaomi Corporation-Prospectus. http://www.hkexnews.hk/ APP/SEHK/2018/2018050202/Documents/ SEHK201805030005.pdf

“Xiaomi's Ecosystem”, 18 April 2018. CMS Research. http:// img3.gelonghui.com/pdf201804/pdf20180419133513809. pdf

“Xiaomi’s Growth Path”, May 2018. ChinaLabs. http://t.cj. sina.com.cn/articles/view/6418632331/ $17 \mathrm{e} 948 \mathrm{e} 8 \mathrm{~b} 00100 \mathrm{f} 6 \mathrm{fn}$

Xiaomi posts $71.7 \%$ jump in 2Q2019 net profit, beating consensus. http://blog.mi.com/en/2019/08/20/xiaomi-posts71-7-jump-in-2q2019-net-profit-beating-consensus/ \#targetText=In\%20June\%202019\%2C\%20MAU\% 20of,22.6\%20million\%20in\%20June\%202019

Publisher's Note Springer Nature remains neutral with regard to jurisdictional claims in published maps and institutional affiliations. 